\title{
Selected Reference Books of 1956-1957
}

\section{INTRODUCTION}

IKE the preceding articles in this L semi-annual series ${ }^{1}$ this survey is based on notes written by members of the staff of the Columbia University libraries. Notes written by assistants are signed with initials. ${ }^{2}$

As the purpose of the list is to present a selection of recent scholarly and foreign works of interest to reference workers in university libraries, it does not pretend to be either well-balanced or comprehensive. Code numbers (such as A11, 1A26, 2S22) have been used to refer to titles in the Guide 3 and its Supplements.

\section{BibLIOGRAPHY}

Masanov, I. F. Slovar' psevdonimov russkikh pisatelei, uchenykh $i$ obshchestvennykh deiatelei. Moskva, Izdvo Vsesoiuznoi knizhnoi palaty, 1956- . Tom 1. A-I. 25r.

Between 1941 and 1949 a three-volume list of Russian pseudonyms (Guide Al18) was published by the All-Union Book Chamber in Moscow. That work is referred to in the present edition as an "abbreviated" version of the file which Masanov started to collect in 1900 . The new edition is considerably enlarged, but omits the extensive introduction by Masanov, who died in 1945. Printed sources for the attributions are indicated in most cases. The list is essentially a general one, embracing Russian authors,

${ }^{2} \mathrm{CRL}$, January and July issues starting January,

252. Reference: Elizabeth Bryce, Eleanor Buist, Eugene Sheehy, John Neal Waddell, Suzanne F. Wemple.

8 Constance M. Winchell, Guide to Reference Books (7th ed.; Chicago; ALA, 1951); Supplement (ChiALA, 1956).

Miss Winchell is Reference Librarian, Columbia University Libraries. scientists, and persons engaged in social and political affairs, with no stated chronological limits. Four volumes are planned, volumes 1-3 to contain Russian, Latin and Greek pseudonyms in separate alphabets and a list of other symbols, with a name index in volume 4.-E.Bu.

\section{ENCYCLOPEDIAS}

Dizionario enciclopedico italiano. Roma, Istituto della Enciclopedia italiana, 1955-57. v.1-6. il. (In progress) $\$ 28$ per vol.

Contents: v.1-6, A-Lieb. To be in 12 Vols. An encyclopedic dictionary giving meanings of words with etymologies, and concise encyclopedic articles. These are not signed and have no bibliographies. The articles are much briefer than those in the Enciclopedia Italiana, e.g., that on Africa in the Enciclopedia extends to almost 100 pages and is profusely illustrated while in the Dizionario there is an article of seven pages with six pages of illustrations. However, the Dizionario has many useful features, such as: a large amount of minor biography, characters of fiction, titles of individual works of literature, gazetteer information, detailed discrimination of word meanings, etc. Illustrations are excellent, some in color, and more numerous than in most encyclopedias. This should be a useful up-to-date complement to the Enciclopedia.

\section{Periodicals}

American Periodicals 18 th Century1800-1850; a Consolidated Index to the Microfilm Series of 18th Century Periodicals and ... 1800-1850 Series. Ann Arbor, University Microfilms, 1956- . Years 1-10 (reels 1-400).

This ten-year index will both facilitate and stimulate use of the more than 600 titles now available through the two American 
periodical microfilm projects (American periodical series. 18th century periodicals; and American periodical series ser.2; $\left.1800_{-}\right)$. Standard entries are followed by indication of the portions microfilmed, and reference to the reel on which each portion appears; reels in the eighteenth century series are so marked. A final index is planned upon completion of the series.E.S.

\section{Bibliografija rasprava, ćlanaka $i$ književ-} nih radova [Glavni redaktor: Mare Ujevic ${ }_{]}$Zagreb, Leksikografski Zavod, 1956 - . v. 1 (in 2)- . $\$ 15$ per vol. $\$ 12$ by subscription.

Contents: Vol. 1, Study of literature; Part 1, Generalities, theory of literature, comparative literature; Part 2, History of Yugoslav literature.

Projected to be complete in twenty-five volumes this work aims to furnish a comprehensive record of all important articles published in Yugoslavia since 1800 in magazines, newspapers, yearbooks, collections, etc. In this first volume over 50,000 articles, dealing with literature in general and with the history of Yugoslav literature, are listed. Each future volume will cover a different subject field. Arrangement is alphabetical by authors; anonymous works are listed before the authors. There are separate indexes of subjects, of authors and of pseudonyms and initials.-S.F.W.

\section{Letopis' periodicheskikh izdanii SSSR} 1950-1954 gg.; bibliograficheskii ukazatel'. Moskva, Izd-vo Vsesoiuznoi knizhnoi palaty, 1955. 552p., errata sheet. 26r.20k.

A bibliography of periodicals published in the USSR between 1950 and 1954, in all languages. Part $I$ is devoted to journals, in classified arrangement; Part II lists newspapers by place of publication. Each part has alphabetical indexes.

Previous volumes were annuals. It is now planned to publish a complete bibliography of this type for five-year periods, with annual supplements limited to new serial titles, changes and deaths.-E.Bu.
Mott, Frank Luther. A History of American Magazines. v.4, 1885-1905. Cambridge, Harvard University Press, 1957. 858p. $\$ 12.50$.

This most recent volume in the series continues the plan of the earlier volumes (Guide E9), except for the omission of a chronological listing of magazines founded during the period covered.

The first section begins with a general discussion of the magazine publishing of the period and continues with chapters on various types of magazines. The second section, called the Supplement, consists of detailed descriptions, alphabetically arranged, of "the more important magazines founded within the period . . . which are not limited by the end-date of the period but are brought down to the present or to the magazine's own end-date." The volume is well indexed and copiously footnoted and illustrated.-E.Br.

Paris. Bibliotheque nationale. Département des periodiques. Périodiques slaves en caracteres cyrilliques; etat des collections en 1950. Paris, 1956. 2 v. $3500 \mathrm{fr}$. per vol.

The holdings of twenty Paris libraries and twenty-six French university libraries are represented in this union list of periodicals, other than newspapers. Russian, Ukrainian, Belorussian, Bulgarian and Serbian titles are arranged in a single alphabet. The earliest version of the title, in the original orthography, has been selected as the main entry. There is an index of journals which have alternate titles in non-Cyrillic characters, as well as a brief chart in French on the evolution of the Academy of Sciences of the USSR. Slavic periodicals in Latin characters (Polish, Czech, Croatian) are to be listed in the Bibliothèque Nation. ale's general Catalogue collectif des periodiques now in progress, but reported not available to libraries.-E.Bu.

Periodicheskaia pechat' SSSR, 1917. 1949; bibliograficheskii ukazatel'. Moskva, Izd-vo Vsesoiuznoi knizhnoi palaty, 1955- . [ $\mathrm{v} .2$ ] Zhurnaly, trudy, 
i biulleteni po estestvennym naukam i matematike. 1956. 220p. 12r.

[v.4] Zhurnaly, trudy i biulleteni po transportu, sviazi i kommunal'nomu delu. 1955. 123p. 9r.50k.

This is the definitive Soviet bibliography of periodicals, other than newspapers, published in the USSR in all languages, up to 1950. Each of the nine volumes contains the titles of journals, transactions, bulletins, etc. in a group of related subject fields, in classified arrangement. There are three alphabetical indexes: titles, places of publication, and publishing institutions and organizations. The tenth volume is to contain master indexes. Each periodical receives full bibliographical description under the latest title; there are cross references to and from earlier titles.

The nine volumes, as yet unnumbered, are usually referred to in the following order, but are being published as completed: journals, etc. in the fields of politics and economics; natural sciences and mathematics; technology and industry; transport, communications and municipal affairs; agriculture; science and education; language, literature and art; medicine, physical culture and sport; publishing, printing, library literature and bibliography.-E.Bu.

\section{Predvaritel'nyi spisok periodicheskikh} izdanii Rossii 1901-1916 godov. Leningrad, 1949. 306p. (Materialy po bibliografii periodicheskikh izdanii; Gosudarstvennaia Publichnaia biblioteka im. M.E. Saltykova-Shchedrina)

Although this is a preliminary list published in 1949, it fills an important gap in the bibliography of Russian periodicals. Approximately 14,000 titles are included, with brief notation as to span of publication and periodicity; arrangement is by place of publication.-E.Bu.

\section{Dissertations}

Index to American Doctoral Dissertations, 1955-56. Ann Arbor, Mich., University Microfilms, 1957. 171p.

This listing serves at the same time as an index to Dissertation Abstracts (Supplement 1G2) and as a continuation of Doctoral Dissertations Accepted by American Universities (Guide G10). Issued as number thirteen of Dissertation Abstracts, it consolidates into one list dissertations for which doctoral degrees were granted in the United States during the academic year 1955-56, and those available on microfilm.-E.Br.

\section{Social Sciences}

Dictionnaire des sciences économiques. Publie sous la direction de Jean Romeuf . . Paris, Presses universitaires de France, 1956- . v.1- . (In progress) $\$ 9$ per vol.

Contents: v.l, A-I.

Published in French, but international in scope, the dictionary includes those terms generally employed in the study of economics. Terms from related fields (political economy, statistics, etc.) necessary to the understanding of economic theory are also included, but not those used in the ordinary dictionary sense. There are biographical sketches of significant figures, excluding living persons. Articles vary in length from a few lines to several pages; many are signed; and some have brief bibliographies. The second volume will include an index of names of authors cited.-E.S.

Ente per la storia del socialismo e del movimento operaio italiano. Bibliografia del socialismo e del movimento operaio italiano. Tomo 1, Periodici. Roma, 1956. 1427p. (In progress) L. 12,000 .

A comprehensive bibliography on the socialist and labor movements in Italy to be published in 3 volumes. Volume 2 will cover books, and volume 3 government documents. The first volume is a checklist of the serial publications of Italian labor parties, workers' movements, unions, etc., issued from 1848-1950. Based entirely upon the holdings of the Biblioteca Nazionale Centrale di Firenze, it includes 3866 items with full bibliographical description for each entry. Arrangement is alphabetical, with indexes classified by (1) political parties; (2) 
trades; (3) date of founding; (4) place of publication. There is also an index of supplements and of journals which ceased after a single issue, and an index of personal names.-S.F.W.

\section{DictionaRIES}

Novum glossarium mediae latinitatis $a b$ anno DCCC usque ad annum MCG; edendum curavit Consilium Academiarum Consociatarum ... Copenhagen, Ejnar Munksgaard, 1957- . (In progress).

Contents: Section L ${ }_{1}$ ed. by ${ }_{1}$ Franz Blatt; Index scriptorum mediae latinitatis . . . qui afferuntur in Novo glossario. . . .

The Union Academique Internationale has for some time been sponsoring the production of a series of medieval Latin dictionaries, each specialized according to period or locality of dialect, some in various stages of publication (e.g., Arnaldi, Guide M349), others only in the planning stage.

The volume now making its appearance is one designed to cover the "general" language of authors from the ninth to the thirteenth centuries. Word treatment is primarily lexicographic, i.e., not historical or encyclopedic; thus, this limitation, along with that of the narrower period covered, will mean that the completed work will augment but not replace DuCange. The Index scriptorum, compiled in scholarly detail, constitutes in itself a useful bibliography of the major Latin authors of the period.-J.N.W.

\section{SCIENCE}

Crane, E. J., Patterson, Austin M. and Marr, Eleanor B. A Guide to the Literature of Chemistry. 2d ed. New York, John Wiley, 1957. 397p. \$9.

For thirty years the first edition of this work has been the standard guide in this field, but as it has long been out of date, this second edition will be especially welcome. Thoroughly revised by Eleanor B. Marr, the Guide follows the original plan with the addition of two new chapters. The text has been largely rewritten and the lists of books, periodicals and organizations brought up to date. Chapters cover reference books, periodicals, patents, government publications, trade literature, other sources including theses and unpublished material, and indexes. There is an especially useful discussion of procedure in literature search.

The appendices include lists of chemical symbols and abbreviations, American libraries of interest to chemists, discontinued periodicals, dealers and publishers, etc. This work will be of first importance for the chemical and technical library and very useful as well in the general collections of reference libraries.

\section{Fine ARTs}

New York Historical Society. The New York Historical Society's Dictionary of Artists in America, 1564-1860, by George C. Groce and David H. Wallace. New Haven, Yale University Press, 1957. 759p. $\$ 15$.

"A documented biographical dictionary of painters, draftsmen, sculptors, engravers, lithographers, and allied artists, either amateur or professional, native or foreign-born, who worked within the present continental limits of the United States between the years 1564 and 1860, inclusive." Introd.

Lists almost 11,000 names and when possible gives dates and places of birth and death, chronology and biographical facts, media, and subject matter of work, exhibitions, pupils, and in some instances locations of representative works. Bibliographies of sources are given at the end of each sketch. The dictionary gathers together much material hitherto widely scattered, and should be useful in all general as well as art libraries.

\section{Literature AND LANGUAGE}

Cambridge Bibliography of English Literature, ed. by F. W. Bateson. Vol. 5, Supplement: A.D. 600-1900, ed. by George Watson. Cambridge, University Press, 1957. 710p. $\$ 12.50$.

"The present supplement attempts to list ... publications of scholarly interest in the study of English language and literature 
down to 1900 which have appeared since the original bibliography was prepared some twenty years ago. . . As nearly as possible sections have been brought down to the beginning of the year 1955." Arrangement and scope are virtually identical with those of the original set, as, unfortunately, is the limited form of citationinitials rather than forenames, no publishers, no pagination for journal articles, etc. Nor is there either author or subject index; the latter is partially compensated for by keying each page to the page number of the corresponding material in the basic volumes, so that after a fashion the original index can be used.-J.N.W.

Dictionnaire des oeuvres de tous les temps et de tous les pays: litterature, philosophie, musique, sciences ${ }_{[} \mathrm{par}_{1}$ Laffont-Bompiani. [2. ed.] Paris, S.E.D.E. [ 1955 ] 4 v. il.

Volume des index . . Paris, S.E.D.E. [1955, 293p. \$100 the set.

This is an abridged, French edition of the Dizionario letterario Bompiani (Guide R31) omitting the section on literary movements and on literary characters. The articles are not signed, although some were rewritten. Listing is by the French form of the titles but unfortunately the index of titles in the original languages is not included in this edition.-S.F.W.

Eppelsheimer, Hanns W. Bibliographie der deutschen Literaturwissenschaft, 1945-1953. Frankfurt am Main, Klostermann ${ }_{\text {[c }} \mathrm{c} 1957$ ] $549 \mathrm{p}$.

Designed to fill part of the gap in the bibliographical record of German studies of the last twenty years, this is an excellent, comprehensive bibliography of works published in the western languages during 19451953. It lists books, pamphlets, dissertations, articles, and book reviews; indexing some 200 journals and 250 collections. Arrangement is by broad subjects, the first four chapters dealing with German literature in general and the other ten with different literary periods. There is an author and a subject index.-S.F.W.
Lohf, Kenneth A. and Sheehy, Eugene P. Joseph Conrad at Mid-Century: Editions and Studies, 1895-1955. Minneapolis, University of Minnesota Press, 1957. 114p. $\$ 5.00$.

An enumerative bibliography in two sections: (1) writings by Conrad and (2) works about him. The aim has been to be as comprehensive as possible and in the first section are listed collected works, selected works and editions of individual titles including serializations and translations. The second part lists works about Conrad: books, essays, theses, reviews, and periodical articles in western languages, from 1895 through 1955. Most titles in this section have been checked for accuracy but a few entries from foreign sources could not be verified and are indicated by an asterisk and listed with the source of reference.

Modern Language Association of America. Annual Bibliography. New York, 1956- . Annual.

Woodress, James Leslie. Dissertations in American Literature, 1891-1955. Durham, N.C., Duke University Press, 1957. 100p. $\$ 2.50$.

Two important bibliographies, one representing a change of scope and title, the other a reworking and expansion of earlier, out-dated lists. The Annual Bibliography continues the MLA American Bibliography (Guide R11), but while the latter was confined to American contributions in the field of modern languages, the 1956 compilation is the first step toward making the publication international in scope. Although necessarily selective, the bibliography now includes entries for "books and articles in English, French, German, Spanish, Italian, Portuguese, Scandinavian, and Dutch" from a master list of about 1,000 sources. Arrangement remains substantially the same.

The Woodress compilation lists some 2,500 dissertations written at approximately 100 U.S. and foreign universities. Arrangement is alphabetical by subject in two sections: individual authors, and general topics. Omission of the date in a citation indicates that the work was still in progress.-E.S. 
Montgomery, Guy. Concordance to the Poetical Works of John Dryden. Assisted by Mary Jackman and Helen S. Agoa. Berkeley and Los Angeles, University of California Press, 1957. 722 p. $\$ 12.50$.

This concordance, based on the Cambridge edition of the Poetical Works of John Dryden, edited by George Rapall Noyes, 1920 (revised and enlarged in 1950), was largely prepared by Prof. Montgomery. After his death it was decided to issue the work using IBM machines, although with this method it was necessary to omit quotations, and only the word, poem symbol, and line number could be included. All poems in the main text have been indexed, but not those in the appendices. All prose passages, including stage directions are omitted. For special words omitted see the Preface. This should be a very useful addition to the collection of concordances.

\section{BIOGRAPHY}

Academie royale des sciences, des lettres et des beaux-arts de Belgique. Biographie nationale. Supplement. Bruxelles, Étab. Emile Bruylant, 1956- . v.l-

The first fascicle of this new supplement covers the letters A-Claessens. In the basic set (Guide S70) which began publication in 1860 and was not completed until 1944, the early volumes contained sketches of persons who had died before 1850. This supplement includes articles on persons who have died since that time as well as a few of earlier periods. The sketches vary from a few lines to several pages in length, are signed, and include bibliographies. It is encouraging indeed to have this valuable set continued.

Cattell, Jaques. Directory of American Scholars, a Biographical Directory. New York, R. R. Bowker, 1957. 3d ed. 836p. $\$ 20$.

An important change is to be noted in connection with this third edition, the present volume being limited to "biographies of those working in Philosophy, History, Liter- ature, the Languages, and other related disciplines." Certain other fields (economics, sociology, geography, and political science) which were included in earlier editions were transferred to Volume III of the ninth edition of American Men of Science (Supplement 2N27). The Directory conforms in style and format to the latter work, and cross references to and from that work were included when requested.-E.S.

Manuel, E. Arsenio. Dictionary of Philippine Biography. Quezon City, Filipiniana Publications, 1955- . v.1- . $\$ 22.50$ per vol.

This is the first volume of a proposed multi-volume work planned to include nonliving individuals who have contributed sig nificantly to Philippine culture. Volume one contains a complete alphabet of biographies, limited to no particular period, and varying in length from half a page to about thirty pages. A general index lists subjects by occupation. Each biography begins with birth and death dates, "field of achievement" and parents' names, and continues with a chronological account of the subject's life. Succeeding volumes are to follow the same plan, and a cumulated index is to be included in the final volume.

A list of works, whether of art, music or literature, is given for most of the more important figures, and a bibliography of printed sources is appended to each article, usually followed by an acknowledgment of personal interviews, which were extensively used. Many photographs of individuals, manuscripts, music and paintings are included.-E.Br.

\section{Vaccaro, Gennaro, ed. Panorama degli italiani d'oggi. Roma, Curcio [1956 2 vols.}

Listing some 25,000 living Italians from all professions, this work follows the usual pattern of a "Who's Who." The sketches, based upon information obtained through questionnaires and from printed sources, vary in length depending upon the availability of data. They usually include, besides concise biographical information, lists of publications, addresses and telephone 
numbers. Some entries are duplicated in the Chi $\dot{e}$ ? (Guide S154) but the two works supplement rather than duplicate each other. Revised editions are promised.-S.F.W.

\section{Travel}

Pescarzoli, Antonio, ed. I libri di viaggio e le guide della raccolta Luigi Vittorio Fossati Bellani; catalogo descrittivo. Roma, Edizione di Storia e Letteratura, 1957. 3 vols.

This is the catalog of an important private collection of Italian travel literature comprising over 5,000 books and pamphlets from the earliest times to the present. Although all western languages are represented, the nucleus of the collection consists of works in Italian. With the exception of some 300 rare items on general travel and exploration, all the works deal with Italy, varying from personal narratives to guide books. Listing is chronological under large geographical areas with a separate author index for each section. The bibliographical description is detailed, including excellent notes on collation, bindings, illustrations, dedications, etc.-S.F.W.

\section{History}

Barzun, Jacques and Graff, Henry F. The Modern Researcher. N. Y., Harcourt, Brace, 1957. 386p. $\$ 6$.

Although much of the text is concerned with research problems in history and allied fields, "this book is for anyone who is or will be engaged in research and report writing, regardless of his field of interest." (Foreword.) It is, indeed, general in subject application, and potentially valuable as well to many librarians, teachers, and editors concerned with the research of others. The authors have skillfully combined a manual of research methods, an essay on the evaluation and interpretation of facts, and a textbook on the writing of acceptable expository English; of particular interest to the librarian are the thorough and practical chapters on literature searching, verification, citations, and quotations, as well as those on word choice and the structure of sentence and paragraph. There are useful tables and dia- grams included, and a detailed bibliography. Not least among the authors' achievements is a stylistic excellence of their own, all too rarely found in manuals of composition.J.N.W.

Beers, Henry Putney. The French in North America; a Bibliographical Guide to French Archives, Reproductions, and Research Missions. Baton Rouge, Louisiana State University Press, 1957. 413p. $\$ 12.50$.

Presents "a history of the activities of American and Canadian institutions, historians, and others connected with the procurement of reproductions in the form of transcripts, photostats, and microfilm from French archives and manuscript collections." Treats public and ecclesiastical records and private manuscripts, tracing the origin of the various missions and describing the reproductions obtained. Emphasis is on material relating to U.S. history, but a chapter on Canadian activities in French archives is included. An extensive bibliography and a detailed index make the volume an effective reference tool.-E.S.

Bibliographie annuelle de l'histoire de France $d u$ cinquieme siecle à 1939. Année 1955- . Paris, Editions du Centre national de la recherche scientifique, 1956- . (Comite français des sciences historiques) $1600 \mathrm{fr}$.

This new annual includes both book and periodical materials on the history of France from the barbarian invasions to 1939, the first volume listing 4,890 studies published in France and elsewhere during 1955. Serving as a successor to Repertoire bibliographique de l'histoire de France by Caron and Stein (Guide V236), the present compilation follows, with certain modifications, the subject arrangement of that work. There are separate subject and author indexes. Prof. Andre Aymard has contributed an "Aperçu bibliographique sur les publications récentes concernant la Gaule antique, 1945 a 1955." -E.S.

Bonser, Wilfrid. An Anglo-Saxon and Celtic Bibliography (450-1087). Berk- 
eley, University of California Press, 1957. 2 v. $\$ 18.50$.

Embracing Anglo-Saxon and Celtic history in the widest sense of the term, this impressive compilation lists in classified subject arrangement 11,975 items on "all aspects of the period, as pertaining to the whole of the British Isles, from the coming of the Saxons, c. 450 A.D. till 1087." Entries include articles in periodicals and Festschriften to 1953, monographs, and textbooks. Brief editorial notes are sometimes provided, but no attempt is made to evaluate the items. Material dealing with literature and linguistics, as such, is excluded. Although it duplicates numerous listings in such bibliographies as those of Chevalier and Potthast, the compiler points out their complementary aspects. The separate index volume contains an author index and a detailed topographical index.-E.S.

Danske historiske forening. Dansk historisk bibliografi, 1943-1947, ved Henry Bruun. København, Hagerups, 1956. $594 \mathrm{p}$.

This is the first of a series of bibliographies to be issued by the Danske historiske forening, aiming to furnish a complete record of writings on Danish history. Similar in scope and arrangement to Erichsen and Krarup, Dansk historisk bibliografi (Guide V206) it lists over 9,000 books and articles published during 1943-1947. There is another volume in preparation which will cover 1913-1942, thus filling the gap between Erichsen and Krarup and the present work. Future volumes will cover five year periods. -S.F.W.

\section{Fenton, William N. American Indian} and White Relations to 1830. Chapel Hill, N.C., University of North Carolina Press, 1957. 138p. (Needs and opportunities for study series.)

The major section of this two-part work is a selective bibliography, compiled by L. H. Butterfield, Wilcomb E. Washburn and William N. Fenton, "to serve the needs of graduate students and those directing their studies." Its stated purpose is to bring together in one list outstanding studies of Indian-white relations, whether in the humanities or the social sciences. An introductory paragraph cites general bibliographic aids which may be useful to the specialist. The section on manuscript sources gives locations of collections throughout the United States and in Canada. Mr. Fenton's introductory essay, based on a paper read before the Institute of Early American History and Culture, provides a brief survey of the field and suggests areas for further study.-E.Br.

Ramos, Roberto. Bibliografía de la historia de Mexico. Mexico, D.F. [the author?] $1956.772 \mathrm{p}$.

A listing of 4,700 items, this bibliography includes monographs, government documents, manuscripts, pamphlets, broadsides, etc. (but not periodical articles), treating the history of Mexico from its discovery up to the period of the twentieth-century Revolution. (For treatment of the latter, see the same author's Bibliografia de la revolución mexicana, Guide V378.) Publications through 1955 are included, and citations are generally adequate, with indication of one library location for each item. Unfortunately, the arrangement is a single listing, alphabetical by author or other main entry, with no period division, nor is there any subject index.-J.N.W.

Vallinkoski, Jorma. Suomen historiallinen bibliografia 1926-1950. Finsk historisk bibliografi. Bibliographie historique finlandaise. Helsinki ${ }_{[}$Forssan kirjapaino oy.j 1955- . v.1- .

(Suomen historiallinen seura käsikirjoja. IV: 1- .)

Compiled under the direction of a committee representing various Finnish learned societies, the work will be complete in two volumes, listing approximately 25,000 items in a subject arrangement. It continues the bibliography for the 1901-25 period by Maliniemi and Kivikoski (Guide V219), and follows the plan and precedents established by that compilation. The great bulk of material is again in Finnish. The second volume will include an index.-E.S. 
Writings on American History .... Index, 1902-1940. Washington, D.C., American Historical Association, 1956 [i.e. 1957 1115p. $\$ 10$.

Long awaited by historians and librarians, this cumulative index to the annual volumes (Guide V101, V102) will be gratefully received, largely for its obvious value as a time saver. According to the foreword, it "is not merely a consolidated or cumulative index $x_{1} \ldots$ it contains references and sub- ject classifications which will not be found in the separate indexes." Unfortunately, the converse seems to be true as well; there are many subject subdivisions appearing in the annual volumes which have been eliminated in the cumulation, or so curtailed as to render them of little value. This has doubtless been necessitated by the attempt to keep publication costs within reason, as have the very small type size and the cluttered format of the column. In each case the reader suffers.-J.N.W.

\section{Portrait of a Library}

Professors under glabrous domes

Are annotating ancient tomes,

While students, thinking them a bother,

Are more concerned with one another.

Sh! Quiet over there!

Librarians with knowing looks

Are hovering over reference books.

They file the things so we can use them

But still contrive some way to lose them.

Sorry, that one's out.

Among the stacks assistants lurk:

They substitute a "hush" for work,

But quickly stop what they aren't doing

Upon the smell of coffee brewing.

Let's take five.

Semester's end will find it packed

With students frantic for a fact:

The documented theme assignment

Is torture's ultimate refinement.

What? Closing already?

Vexations often make us doubt it,

But sore would we be off without it.

Robert C. Wylder in AAUP Bulletin

(November, 1957) 